\title{
Tubercular Mastitis - A Great Masquerader
}

\author{
Tüberküloz Mastiti - Büyük Taklitçi
}

\author{
Sonia GON, Aditi BHATTACHARYYA, Bipasa MAJUMDAR, Soumya KUNDU
}

Department of Pathology, R G Kar Medical College \& Hospital, KOLKATA, INDIA

\begin{abstract}
Tubercular mastitis is a rare clinical entity as mammary gland tissue, like spleen and skeletal muscle, offers resistance to the survival and multiplication of the tubercle bacillus. Tuberculosis of the breast can mimic carcinoma, whereas in young patients it can be mistaken for a pyogenic breast abscess, thus labeled a "great masquerader" in recognition of its multifaceted presentation. Breast tuberculosis commonly affects women in the reproductive age group, between 21 and 30 years, and is rare in prepubescent females and elderly women. Fine needle aspiration cytology is very useful and it is a promising technique in expert hands. In tuberculosis-endemic countries, the finding of granuloma on fine needle aspiration cytology warrants empirical treatment for tuberculosis even in the absence of positive acid-fast bacilli and without culture results. We hereby report a case of tubercular mastitis in a post-menopausal seronegative female diagnosed on fine needle aspiration cytology with a positive acid-fast bacilli and a review of the recent literature.
\end{abstract}

Key Words: Tuberculosis, Breast, Serology, Postmenopause

\section{ÖZ}

Tüberküloz mastitis, meme dokusu dalak ve çizgili kas gibi tüberküloz basilinin yaşaması ve çoğalmasına karşı direnç gösterdiği için nadirdir. Meme tüberkülozu kanseri taklit edebilir ve genç hastalarda ise pyojenik abse ile karıştırılabilir. Bu nedenle de "büyük taklitçi" olarak isimlendirilir. Meme tüberkülozu üreme çağı kadınlarda, 21-30 yaşlarında daha sıktır ve ergenlik öncesi ve yaşlılarda nadirdir. Tüberkülozun endemik olduğu ülkelerde ince iğne aspirasyon biyopsisi yetkin ellerde yapıldığında önemlidir ve sitolojide granülomların görülmesi asit-fast basil görülmese bile, kültür sonucu beklenmeden ampirik tedaviye başlanmasını gerektirir. Burada, ince iğne aspirasyon biyopsisi ile tüberküloz mastit tanısı konan bir postmenopozal olgu literatür bilgileri ışığında sunulmaktadır.

Anahtar Sözcükler: Tüberküloz, Meme, Seroloji, Postmenopoz

\section{INTRODUCTION}

Tuberculosis of the breast has been labeled a "great masquerader" in recognition of its multifaceted presentation (1). It comprises approximately $0.025 \%$ to $0.1 \%$ of all surgically treated diseases of the breast in western countries and between $0.64 \%$ and $3.59 \%$ of all mammary conditions in India $(2,3)$. Many new diagnostic modalities and ancillary techniques have been developed since its first documentation by Sir Astley Cooper in 1829 as a 'scrofulous swelling of the bosom' (4).

Fine needle aspiration cytology (FNAC) is very useful and a promising technique in expert hands. In tuberculosisendemic countries, the finding of granuloma in FNAC warrants empirical treatment for tuberculosis even in the absence of positive acid-fast bacilli (AFB) and without culture results (5).
We hereby report a case of tubercular mastitis in a postmenopausal female diagnosed on FNAC with a positive $\mathrm{AFB}$ and review of the recent literature.

\section{CASE REPORT}

A 50-year-old multiparous, postmenopausal female was referred to the department of pathology for FNAC of a progressively increasing painless lump of 3 months duration in the right breast. On local examination, the lump measured $2 \times 1 \mathrm{~cm}$ and was firm, non-tender, and mobile in the upper outer quadrant, located subcutaneously. The nipple, areola and overlying skin were normal. There was no axillary or cervical lymphadenopathy and a provisional clinical diagnosis of skin adnexal tumor was made. The left breast was normal.

There were no significant past history and no associated constitutional symptoms. Chest radiograph, routine hematological and biochemical investigations were within

Correspondence: Sonia GON

Department of Pathology, R G Kar Medical College \& Hospital,

KOLKATA, INDIA

E-mail: drmarur@yahoo.com Phone: +919433348978 
normal limits apart from mild leukocytosis and mildly raised ESR. HIV status was non reactive.

The lump was subjected to FNAC and pus-like material was aspirated. Microscopically, MGG-stained smears revealed ill-formed epithelioid cell granulomas, Langhans' giant cells and inflammatory cells on a background of necrosis. A few clusters of ductal epithelial cells were also found (Figure 1). Ziehl-Neelsen staining of the aspirate was positive for acid fast bacilli (Figure 2). Based on the FNAC diagnosis, the patient was put on anti tubercular therapy and the swelling greatly reduced in size after the one-month follow-up period.

\section{DISCUSSION}

Tubercular mastitis is a rare clinical entity as mammary gland tissue, like spleen and skeletal muscle, offers resistance to the survival and multiplication of the tubercle bacillus (6).

Mammary tuberculosis may be primary, when no demonstrable tuberculosis focus exists, or secondary to a lesion elsewhere in the body. Although it was initially believed that as much as $60 \%$ of breast tuberculosis was primary, it is now accepted that mammary tuberculosis is almost invariably secondary to a lesion elsewhere in the body. Primary infection of the breast, through abrasions in the skin or through the duct openings on the nipple, is also a possibility.

The most common mode of infection is thought to be retrograde lymphatic spread from the pulmonary focus through the para-tracheal and internal mammary lymph nodes. Hematogenous spread and direct extension from contiguous structures are other modes of infection (6). The present case had no palpable lymphadenopathy or pulmonary focus demonstrable on chest $\mathrm{x}$-ray and primary or secondary infection could not be established due to the lack of evidence of tuberculosis in other sites.

Breast tuberculosis commonly affects women in their reproductive age group, between 21-30 years, may be because the female breast undergoes frequent changes during the period of activity and is more liable to trauma and infection (3). It is rare in males, prepubescent females and elderly women (7). Interestingly, the present patient was post-menopausal and did not have any past history of mastitis or trauma and was also seronegative for AIDS.

Tuberculosis of the breast can mimic carcinoma, whereas in young patients it can be mistaken for a pyogenic breast abscess, thus labeled a "great masquerader" in recognition of its multifaceted presentation (1). Less common differential

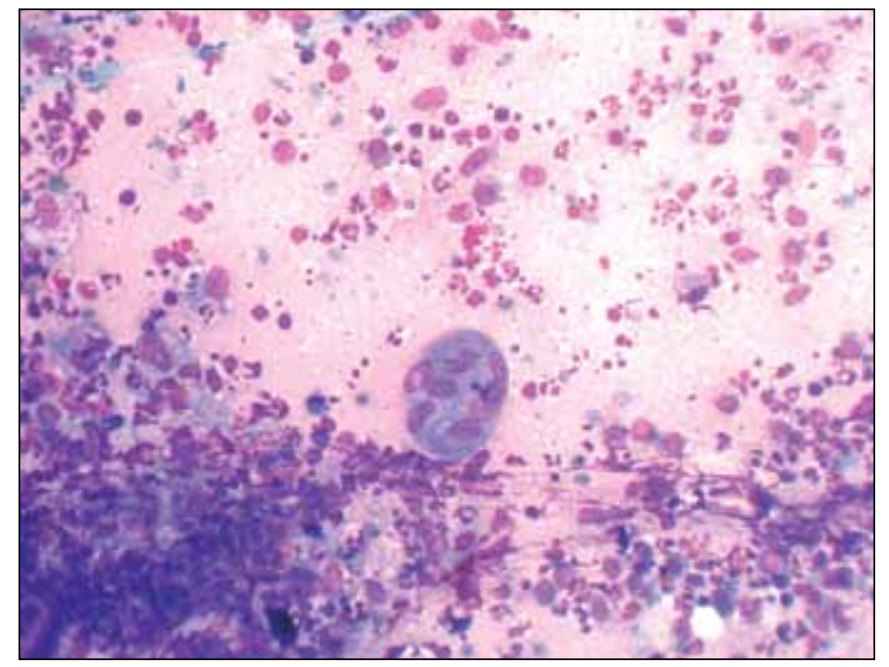

Figure 1: Ill-formed epithelioid cell granulomas, Langhans' giant cells and inflammatory cells along with a few ductal epithelial cells on a necrotic background (MGG, $\mathrm{x} 40$ ).

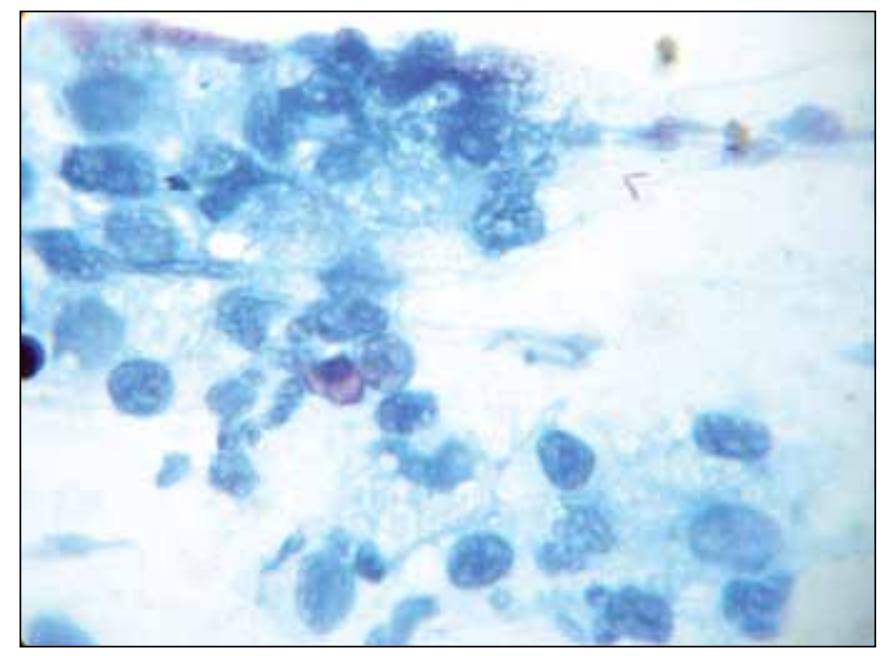

Figure 2: Acid fast bacilli in the upper right corner. Note the presence of an occasional ductal epithelial cell (Ziehl Neelsen, $\mathrm{x} 100)$.

diagnoses are traumatic fat necrosis, plasma cell mastitis, chronic pyogenic abscess, mammary dysplasia, fibroadenoma, granulomatous mastitis, sarcoidosis, blastomycosis and actinomycosis (1).

There are three clinical varieties of mammary tuberculosis, namely nodular, disseminated, and sclerosing. The nodular variety is the most common and mimics fibroadenoma or carcinoma, the diffuse variety presents with caseation and sinus formation, whereas the sclerosing variety shows extensive fibrosis with hard lumps resembling carcinoma (9). Due to proximity of the axillary nodes, the upper outer quadrant of breast is the most frequently involved site, though any area of the breast can be involved (10). 
The present case had a lump in the outer upper quadrant of the right breast and belonged to the nodular variety of mammary tuberculosis.

The demonstration of AFB on FNAC is not mandatory, since the number of AFB must be 10,000-100,000/ml of material to be seen microscopically (3). Demonstration of caseating granulomas with Langhans' giant cells from the breast tissue and involved lymph nodes may therefore be sufficient for the diagnosis (5). The Mantoux test is usually positive in adults in endemic areas for tuberculosis and is of no great help for the diagnosis of breast tuberculosis (3). Mammography and ultrasonography do not clinch the diagnosis as features are largely nonspecific. Though mycobacterial culture remains the gold standard for diagnosis of tuberculosis, the time required and frequent negative results in paucibacillary specimens are important limitations. Moreover, culture is not always helpful in the diagnosis of breast tuberculosis. PCR is by no means absolute in diagnosing tubercular infection and false negative reports are still a possibility (3). In the present case, FNAC was done as a first line screening test and it clinched the diagnosis. The patient was therefore not subjected to the Mantoux test, culture, ultrasonography, mammography or PCR.

All patients should receive adequate systemic chemotherapy i.e. anti-tubercular therapy. After complete anti tubercular therapy, residual lumps localized to a quadrant should be excised via segmental or sector mastectomy. In extensive cases, a simple mastectomy has been advocated. Radical mastectomy is best avoided unless there is a co-existing malignancy (5). In the present case, the patient was given anti-tubercular therapy and the swelling decreased in size considerably within one month.
To conclude, though tubercular mastitis is a rare clinical entity, awareness of this disease is important for both the surgeon and the pathologist. FNAC as a first-line screening modality may lead to avoidance of other expensive ancillary diagnostic tests such as mammography and PCR.

\section{REFERENCES}

1. Mehmood N, Zeeshan HK, Khan UA, Nawaz A, Malik IA, Khan MI: Tuberculous mastitis- Presentation and outcome in our setup. Ann Pak Inst Med Sci 2009, 5: 245-250

2. Kalac N, Ozkan B, Bayiz H, Dursun AB, Demirag F: Breast tuberculosis. Breast 2002, 11:346-349

3. Kant S, Dua R, Goel MM: Bilateral tubercular mastitis: A case report. Lung India 2007, 24:90-93

4. Cooper AP: Illustrations of the diseases of the breast. London, Longman Rees Co., 1829, 73

5. Tauro LF, Martis JS, George C, Kamath A, Lobo G, Hegde BR: Tuberculous mastitis presenting as breast abscess. Oman Medical Journal 2011, 26:53-55

6. Bannerjee SN, Ananthakrishran N, Mehta RB, Parkash S: Tuberculous mastitis: A continuing problem. World J Surg 1987, 11:105-109

7. Hamit HF, Ragsdale TH: Mammary tuberculosis. J R Soc Med 1982, 75:764-765

8. Kao T, May YT, Sai HT, Hon-Kwong M: Tuberculosis of the breast with erythema nodosum: A case report. J Med Case Rep 2010, 4:124

9. Godara R, Ahuja V, Dhingra A, Sushila, Sen J, Singh R: Tubercular mastitis masquerading as carcinoma: A case report. Internet Journal of Surgery 2007, 13

10. Gupta PP, Gupta KB, Yadav RK, Agarwal D: Tuberculous mastitis. A review of seven consecutive cases. Ind J Tub 2003, 50: 47-50 